\title{
DAMPAK SOSIAL EKONOMI KEBERADAAN USAHA PETERNAKAN AYAM RAS PETELUR, DI DESA SENGANAN, KECAMATAN PENEBEL, KABUPATEN TABANAN
}

\author{
I Gusti Agung Nyoman Dananjaya,S.P.,M.Agb \\ Program Studi Agribisnis, Fakultas Pertanian, Universitas Dwijendra \\ Email : guz.d4nan@gmail.com
}

\begin{abstract}
Abstrak
Usaha peternakan ayam ras petelur memiliki dampak positif dan negatif tehadap lingkungan, khususnya masyarakat yang bertempat tinggal di sekitar usaha peternakan ayam ras petelur. Tujuan penelitian ini adalah untuk mengetahui dampak sosial ekonomi dan lingkungan usaha peternakan ayam ras petelur yang bertempat tinggal disekitar lokasi peternakan di Desa Senganan, Kecamatan Penebel di Kabupaten Tabanan.Pemilihan lokasi ini ditentukan secara purposive sampling yaitu teknik penentuan sampel lokasi secara sengaja atau dengan pertimbangan tertentu. Adapun pertimbangannya adalah masyarakat yang bertempat tinggal di Desa Senganan dan berdekatan dengan usaha peternakan ayam ras petelur. Populasi pada penelitian ini adalah masyarakat yang bukan peternakan yang ada di sekitar lokasi peternakan yang ada di Desa Senganan. Teknik pengambilan sampel pada penelitian ini menggunakan metode quota sampling sehingga seluruh responden berjumlah 67 orang.Analisis data yang digunakan pada penelitian adalah dengan menggunakan metode deskriptif kualitatif dan kuantitatif.

Hasil penelitian menunjukkan bahwa dampak sosial dan ekonomi usaha peternakan ayam ras petelur di Desa Senganan, Kecamatan Penebel, Kabupaten Tabanan berada dalam kategori baik dengan perolehan skor 3,64 dan 3,68 sedangkan dilihat dari dampak lingkungan masyarakat sekitar berada pada kategori cukup dengan perolehan skor 3,10. Saran bagi usaha peternakan ayam ras petelur yaitu Peternak harus memperhatikan masalah kesehatan lingkungan dari segi limbah ternak agar masyarakat tidak terganggu dan Dinas Peternakan terkait harus memberikan penyuluhan mengenai cara penanganan limbah ternak ayam agar tidak mencemari lingkungan di sekitar Desa Senganan.
\end{abstract}

Kata kunci:Dampak Sosial Ekonomi, Usaha Peternakan, Ayam Ras Petelur

\begin{abstract}
Laying breed chicken farms have positive and negative impacts on the environtment, especially for the people who live around the laying breed chicken farms. The purpose of this study was to determine the socio economic and environmental impact of laying broilers who live around the farm in Senganan Village, Penebel District, Tabanan Regency. The location selection was determined by purposive sampling, namely the technique of determining the location sample intentionally or with certain considerations. The consideration is that the people who live in Senganan Village and close to the laying breed chicken farm. The population in this study were non-farm communities around the farms in Senganan Village. The sampling technique in this study used a quota sampling method so taht all respondents totaled 67 people. The data analysis used in this research is descriptive qualitative and quantitative methods.

The results showed that the social and economic impact of laying breed chicken farm in Senganan Village, Penebel District, Tabanan Regency was in a good category with a score of 3,54 and 3,68, while seen from the environmental impact of the surrounding community, it was in the moderate category with a score 3,10. Suggestion for layong breed chicken farms are that breeders must pay attention to environmental health problems in terms of livestock waste so that the community is not disturbed and the relevant Animal Husbandry Service must provide counseling on how to handle chicken livestock waste so as not to pollute the environment around Senganan Village.
\end{abstract}

Keyword : Socio Economic Impacts, Animal Husbandry Business, Layer Chicken

\section{PENDAHULUAN}

Sektor pertanian memiliki peranan yang sangat penting untuk mensejahterakan masyarakat perdesaan yang juga merupakan mata pencaharian utama masyarakat perdesaan (Sedana and Astawa, 2016; Sedana and Rahmat, 2020). Sektor pertanian juga dapat dijadikan penggerak untuk meningkatkan pendapatan masyarakat dan menciptakan lapangan kerja (Sedana, 2020). Salah satu subsektor pertanian 
dalam arti luas diantaranya adalah peternakan. Peternakan memegang peranan cukup penting dalam mewujudkan kesejahteraan masyarakat tertuama dalam memenuhi kebutuhan akan protein hewani, menyediakan lapangan kerja, meningkatkan pendapatan serta mendukung munculnya industri yang berbahan baku peternakan. Adanya wabah virus COVID 19 mengakibatkan menurunnya kunjungan wisatawanyang mengakibatkan menururnya pendapatan di sektor pariwisata. Hal ini mendorong pemerintah Provinsi Bali berupaya lebih menggalakkan sektor pertanian, khususnya sektor peternakan. Dengan demikian para pelaku wisatawan mulai mencari alternatif pekerjaan lain di bidang sektor peternakan.

Perkembangan sektor peternakan, seperti industri perunggasan di Indonesia sudah berkembang sedemikian pesat, walaupun masih dihadapkan pada berbagasi kendala yang semakin berat dan kompleks. Oleh karena itu, tidak mengherankan bila saat ini usaha peternakan ayam ras diklasifikasikan sebagai usaha ekonomi yang memerlukan modal yang cukup besar (Murtijo, 1987). Dalam keadaan situasi kemiskinan dan krisis ini juga membuat orang menjadi sadar bahwa pertanian tidak selayaknya hanya sekedar sebagai "pendukung" melainkan "mesin penggerak" perekonomian nasional. Pembangunan peternakan merupakan salah satu aspek yang penting dalam pembangunan pertanian, terutama pada saat krisis ekonomi dan moneter. Peran sub sektor peternakan terhadap pembangunan pertanian, karena dimana sektor peternakan adalah sektor yang memberikan konstribusi tinggi dalam pembangunan pertanian.Untuk meningkatkan pendapatan petani tidak bisa dari sektor pertanian saja, tetap harus dibarengi juga oleh sektor peternakan (Dananjaya, 2020)

Sektor ini memiliki peluang pasar yang sangat baik. Pasar domestik akan terus meningkat seiring dengan pertumbuhannya penduduk yang semakin pesat atau padat. Semakin meningkatnya pendapatan penduduk maka permintaan produk - produk peternakan mengalami peningkatan pula namun masih banyak permasalahan dalam pemasaran telur.Telur ayam ras merupakan bahan pangan yang mengandung protein cukup tinggi dengan susunan asam amino lengkap. Secara umum telur ayam ras merupakan pangan hasil ternak yang sering dikonsumsi oleh masyarakat Indonesia. Telur ayam ras mengandung gizi yang tinggi, ketersediaan yang continue, dan harga yang relatif lebih murah dibandingkan telur lainnya sehingga menjadikan telur ayam ras sangat diminati oleh konsumen.

Adanya interaksi antara manusia dan lingkungannya dapat menimbulkan berbagai dampak, baik positif maupun negatif. Dalam hal ini usaha peternakan ayam ras petelur juga dapat berdampak positif dan negatif tehadap lingkungan, khususnya masyarakat yang bertempat tinggal di sekitar usaha peternakan ayam ras petelur tersebut. Dampak positifnya antara lain dapat membuka lapangan pekerjaan bagi masyarakat sekitar atau membantu mengurangi jumlah pengangguran, di samping memudahkan masyarakat sekitar dapat memberi telur dengan harga yang lebih murah (Pandang, 2004).

Dalam hal ini usaha peternakan ayam ras petelur dapat mengakibatkan pencemaran air jika pembuangan kotoran ayam tidak dikelola dengan baik, misalnya dibuang ke sungai, serta pencemaran udara yang berasal dari bau kotoran ayam. Pencemaran tersebut secara tidak langsung dapat menimbulkan masalah sosial, misalnya air yang biasanya dapat digunakan oleh penduduk untuk kebutuhan sehari-hari seperti memasak, mandi, mencuci dan lain sebagainya. 
Di Provinsi Bali salah satu kabupaten yang paling tinggi populasi pengembangan ayam ras petelur adalah Kabupaten Tabanan. Salah satu desa di Kabupaten Tabanan yang memiliki usaha peternakan ayam ras petelur adalah Desa Senganan. Di desa ini banyak terdapat usaha peternakan ayam ras petelur yang terletak di dekat tempat tinggal penduduk. Hal ini mengakibatkan adanya dampak yang ditimbulkan oleh peternakan ayam ras tersebut. Bau kotoran ayam tersebut bisa mengakibatkan terganggunya kenyamanan masyarakat yang tinggal di sekitar lokasi usaha peternakan ayam tersebut. Berdasarkan uraian di atas, maka peneliti ingin menngetahui bagaimana dampak sosial ekonomi dan lingkungan usaha peternakan ayam ras petelur yang bertempat tinggal disekitar lokasi peternakan di Desa Senganan, Kecamatan Penebel di Kabupaten Tabanan.

\section{METODE}

Penelitian ini dilakukan di Desa Senganan, Kecamatan Penebel, Kabupaten Tabanan. Pemilihan lokasi ini ditentukan secara purposive sampling yaitu teknik penentuan sampel lokasi secara sengaja atau dengan pertimbangan tertentu. Adapun pertimbangannya adalah masyarakat yang bertempat tinggal di Desa Senganan dan berdekatan dengan usaha peternakan ayam ras petelur. Populasi pada penelitian ini adalah masyarakat yang bukan peternakan yang ada di sekitar lokasi peternakan yang ada di Desa Senganan. Teknik pengambilan sampel pada penelitian ini menggunakan metode quota sampling sehingga seluruh responden berjumlah 67 orang.

Data yang digunakan dalam penelitian ini meliputi data primer dan data sekunder baik yang bersifat kualitatif maupun kuantitatif yang berkenaan dengan dampak sosial ekonomi dan lingkungan usaha peternakan ayam ras petelur. Sedangkan teknik pengumpulan data dilakukan dengan menggunakan kuesioner, wawancara, observasi dan dokumentasi.

Analisis data yang digunakan pada penelitian adalah dengan menggunakan metode deskriptif kualitatif dan kuantitatif. Data mengenai identitas pribadi responden dianalisa sampai tahap tabulasi dan dicari frekuensinya. Data mengenai dampak usaha peternakan ayam ras petelur terhadap lingkungan masyarakat bukan peternak meliputi aspek sosial, ekonomi dan lingkungan, dari data kualitatif diubah terlebih dahulu menjadi kuantitatif dengan pemberian skor dan selanjutnya dianalisis secara deskriptif.

\section{HASIL DAN PEMBAHASAN}

\section{Gambaran Umum Daerah Penelitian}

Desa Senganan merupakan salah satu desa yang ada di Kecamatan Penebel, Kabupaten Tabanan, Provinsi Bali. Secara geografis Desa Senganan terletak pada daerah dataran rendah dengan ketinggian 350-500 meter dari permukaan laut dan membentang dari selatan ke utara, dengan luas wilayah 11.800 .00 $\mathrm{m}^{2}$. Dengan jenis tanah lantosol lempung berpasir sehingga sangat cocok dengan daerah pertanian serta budidaya tanaman pangan, perkebunan, tanaman keras dan lain sebagaianya.Ditinjau dari klimatologi Desa Senganan memiliki iklim Tropis, dimana suhu harian rata-rata $28^{\circ} \mathrm{C}$ Rata-rata curah hujan $2.358,572$ $\mathrm{m} /$ th dengan 180 hari hujan, sedangakan distribusi hujan 6 bulan basah dan 6 bulan kering setahun.

Penduduk merupakan salah satu modal dasar dalam pembangunan, karena dilihat dari peranannya, maka penduduk merupakan sumber daya manusia yang memiliki peran sebagai pelaku utama sekaligus 
sebagai pemanfaat hasil pembangunan.Namun bila tidak dikelola dengan baik, penduduk dapat juga menimbulkan permasalahan sosial, seperti pengangguran, kemiskinan, dan masalah sosial lainnya, yang justru dapat menggangu pelaksanaan pembangunan. Berdasarkan hasil data administrasi pemerintahan desa pertahun 2014, jumlah penduduk Desa Senganan adalah 6.897 jiwa, terdiri dari 3.506 jiwa laki-laki dan 3.391 jiwa perempuan, sedangkan sebaran penduduk Desa Senganan terbanyak terdapat di 12 Banjar Dinas. (Anonim, 2020).

\section{Dampak Sosial Usaha Peternakan Ayam Ras Petelur di Desa Senganan}

Indikator yang diamati pada dampak sosial ini meliputi 4 indikator yaitu (1) Adanya saling kunjung mengunjungi antara peternak dan masyarakat sekitar, (2) Adanya interaksi antara peternak dengan masyarakat sekitar dalam upacara keagamaan, (3) Tidak pernah terjadi konflik antara peternak dan masyarakat sekitar, dan (4) Tidak pernah terjadi kesenjangan sosial antara peternak dan masyarakat sekitar. Untuk mengetahui kriteria dampak sosial usaha peternakan ayam ras petelur di Desa Senganan dapat dilihat pada Tabel 1 di bawah ini.

Tabel 1. Dampak Sosial Usaha Peternakan Ayam Ras Petelur di Desa Senganan

\begin{tabular}{|c|l|c|c|}
\hline \multirow{2}{*}{ No } & \multicolumn{1}{|c|}{ Indikator } & Rata-rata & \multirow{2}{*}{ Kategori } \\
\cline { 3 - 3 } & \multicolumn{1}{|c|}{ Skor } & \multirow{2}{*}{ Baik } \\
\hline 1 & $\begin{array}{l}\text { Adanya saling kunjung mengunjungi antara } \\
\text { peternak dan masyarakat sekitar }\end{array}$ & 3,55 & Baik \\
\hline 2 & $\begin{array}{l}\text { Adanya interaksi antara peternak dengan } \\
\text { masyarakat sekitar dalam upacara keagamaan }\end{array}$ & 3,63 & Baik \\
\hline 3 & $\begin{array}{l}\text { Tidak pernah terjadi konflik antara peternak } \\
\text { dan masyarakat sekitar }\end{array}$ & 3,52 & Baik \\
\hline 4 & $\begin{array}{l}\text { Tidak pernah terjadi kesenjangan sosial antara } \\
\text { peternak dan masyarakat sekitar }\end{array}$ & 3,48 & Baik \\
\hline \multicolumn{2}{|c|}{ Dampak Sosial } & $\mathbf{3 , 5 4}$ & \multicolumn{2}{c}{} \\
\hline
\end{tabular}

Sumber : Data diolah dari hasil survai

Berdasarkan hasil penelitian dampak sosial usaha peternakan ayam ras petelur di Desa Senganan termasuk dalam kategori baik, dengan perolehan skor 3,54. Hal ini menunjukkan bahwa hubungan diantara para peternak dengan masyarakat yang terdampak terjalin dengan baik dan masyarakat dapat menerima keberadaan usaha peternakan tersebut. Indikator yang tertinggi berada pada adanya interaksi antara peternak dengan masyarakat sekitar dalam upacara keagamaan, hal ini berarti besar adanya interaksi sosial saling membutuhkan dan adanya kontribusi ayam maupun telur ayam pada saat upacara keagamaan. Karena masyarakat perdesaan sangat sering melakukan upacara keagamaan di desa.

Keberadaan usaha peternakan ini sangat di maklumi oleh masyarakat sekitar karena adanya rasa ikatan dan kebersamaan yang kuat diantara mereka sejak mulai dibangun usaha peternakan. Peternakan usaha ayam tersebut tidak sebagai pengganggu oleh masyarakat sekitar melainkan lebih banyak manfaat dan kontribusinya. Menurut pendapat Pranowo (1985; Sedana et al, 2014) bahwa dalam masyarakat terdapat ikatan kekeluargaan yang erat, kenyataan pada tradisi dan kaidah sosial, serta dalam sistem sosial bukan hanya saling mempengaruhi dan saling ketergantungan dalam perilaku mereka, melainkan interaksi yang mempunyai pola yang cendrung dipertahankan. 


\section{Dampak Ekonomi Usaha Peternakan Ayam Ras Petelur di Desa Senganan}

Indikator yang diamati pada dampak ekonomi ini meliputi 3indikator yaitu (1) Masyarakat diuntungkan dengan adanya usaha peternakan ayam, (2) Masyarakat dapat membuka lapangan pekerjaan, dan (3) Membuka peluang bagi munculnya usaha baru. Untuk mengetahui kriteria dampak sosial usaha peternakan ayam ras petelur di Desa Senganan dapat dilihat pada Tabel 2 di bawah ini.

Tabel 2. Dampak Ekonomi Usaha Peternakan Ayam Ras Petelur di Desa Senganan

\begin{tabular}{|c|l|c|c|}
\hline \multirow{2}{*}{ No } & \multicolumn{1}{|c|}{ Indikator } & Rata-rata & \multirow{2}{*}{ Kategori } \\
\cline { 3 - 3 } & \multicolumn{1}{|c|}{ Skor } & Baik \\
\hline 1 & $\begin{array}{l}\text { Masyarakat diuntungkan dengan adanya usaha } \\
\text { peternakan ayam }\end{array}$ & 3,58 & Baik \\
\hline 2 & $\begin{array}{l}\text { Masyarakat dapat membuka lapangan } \\
\text { pekerjaan }\end{array}$ & 3,67 & Baik \\
\hline 3 & Membuka peluang bagi munculnya usaha baru & 3,79 & Baik \\
\hline & \multicolumn{1}{|c|}{ Dampak Ekonomi } & $\mathbf{3 , 6 8}$ & \\
\hline
\end{tabular}

Sumber : Data diolah dari hasil survai

Hasil penelitian mengenai dampak ekonomi usaha peternakan ayam ras petelur di Desa Senganan termasuk dalam kategori baik dengan pencapaian skor sebesar 3,68. Hal ini menunjukkan bahwa masyarakat di sekitar sangat merasakan manfaat dari segi ekonomi dengan adanya usaha peternakan ayam tersebut. Besar manfaat yang masyarakat dapatkan seperti mereka dapat membeli telur dengan harga yang lebih murah dan warung-warung yang ada di sekitar lokasi menjadi ramai dengan kedatangan pemasok telur dan pembeli kotoran ternak ayam tersebut.

Indikator yang paling tinggi yang dilihat dari dampak ekonomi adalah membuka peluang bagi munculnya usaha baru. Hal ini terbukti dari banyaknya masyarakat sekitar membuka usaha penjualan telur dan ayam potong dan membuka peluang usaha warung-warung kecil serta usaha penjualan pakan dan obat-obatan peternakan sebagai awal dari mulai berbisnis. Adanya peternakan ayam ini sangat membantu masyarakat dalam membuka lapangan pekerjaan di sekitarnya, baik sebagai buruh di peternakan maupun buruh angkut yang disewa oleh pembeli kotoran. Dengan demikian keberadaan usaha peternakan ayam ras petelur di Desa Senganan memberikan manfaat ekonomis bagi masyarakat di sekitarnya.

\section{Dampak Lingkungan Usaha Peternakan Ayam Ras Petelur di Desa Senganan}

Indikator yang diamati pada dampak ekonomi ini meliputi 4 indikator yaitu (1) Masyarakat tidak terganggu dengan bau kotoran, (2) Masyarakat tidak terganggu dengan limbah yang dibuang ke sungai, (3) Adanya pembuangan limbah yang baik oleh peternak, dan (4) Adanya pengolahan dan pemanfaatan kotoran oleh masyarakat sekitar. Untuk mengetahui kriteria dampak sosial usaha peternakan ayam ras petelur di Desa Senganan dapat dilihat pada Tabel 3 di bawah ini. 
Tabel 3. Dampak Lingkungan Usaha Peternakan Ayam Ras Petelur di Desa Senganan

\begin{tabular}{|c|l|c|c|}
\hline \multirow{2}{*}{ No } & \multicolumn{1}{|c|}{ Indikator } & Rata-rata & \multirow{2}{*}{ Kategori } \\
\cline { 3 - 3 } & \multicolumn{1}{|c|}{$\begin{array}{c}\text { Skor } \\
\text { Masyarakat tidak terganggu dengan bau } \\
\text { kotoran }\end{array}$} & 3,25 & \multirow{2}{*}{ Cukup } \\
\hline 2 & $\begin{array}{l}\text { Masyarakat tidak terganggu dengan limbah } \\
\text { yang dibuang ke sungai }\end{array}$ & 3,19 & Cukup \\
\hline 3 & $\begin{array}{l}\text { Adanya pembuangan limbah yang baik oleh } \\
\text { peternak }\end{array}$ & 2,58 & Kurang \\
\hline 4 & $\begin{array}{l}\text { Adanya pengolahan dan pemanfaatan kotoran } \\
\text { oleh masyarakat sekitar }\end{array}$ & 3,36 & Cukup \\
\hline \multicolumn{2}{|c|}{ Dampak Lingkungan } & $\mathbf{3 , 1 0}$ & Cukup \\
\hline
\end{tabular}

Sumber : Data diolah dari hasil survai

Berdasarkan hasil penelitian mengenai dampak lingkungan usaha peternakan ayam ras petelur di Desa Senganan termasuk dalam kategori cukup dengan perolehan skor 3,10. Hal ini menunjukkan bahwa ada beberapa usaha peternak ayam yang jarang memperhatikan kebersihan lingkungan dalam menjalankan usahanya dan kadangkala ada yang membuang kotoran maupun bangkai ayam ke sungai. Kotoran yang dibuang sembarangan tersebut mengakibatkan polusi di Desa Senganan. Menurut pendapat Soeparmo (1988) menyatakan bahwa dalam interaksi manusia dengan lingkungan akan dapat menimbulkan pengaruh positif maupun negatif. Pengaruh positifnya antara lain, limbah yang dihasilkan dapat dimanfaatkan dengan baik, seperti halnya pada peternakan ayam petelur di Desa Senganan ini, sehingga apabila ada konflik lebih bisa cepat teratasi.

\section{PENUTUP}

\section{Simpulan}

Berdasarkan hasil dan pembahasan di atas dapat disimpulkan bahwa dampak sosial dan ekonomi usaha peternakan ayam ras petelur di Desa Senganan, Kecamatan Penebel, Kabupaten Tabananberada dalam kategori baik dengan perolehan skor 3,54 dan 3,68 sedangkan dilihat dari dampak lingkungan masyarakat sekitar berada pada kategori cukup dengan perolehan skor 3,10.

\section{Saran}

Berdasarkan hasilanalisis dan pembahasan yang telah dilakukan dalam penelitian ini, maka dapat diberikan beberapa saran sebagai yaitu(1) Peternak harus memperhatikan masalah kesehatan lingkungan dari segi limbah ternak agar masyarakat tidak terganggu, (2) Peternak dalam mendirikan usaha agar menjaga jarak dari pemukiman masyarakat perdesaaan, (3) Peternak dan masyarakat sekitar agar memanfaatkan kotoran ternak sebagai pupuk organik, (4) Dinas Peternakan terkait harus memberikan penyuluhan mengenai cara penanganan limbah ternak ayam agar tidak mencemari lingkungan. 


\section{DAFTAR PUSTAKA}

Anonim. 2020. "Data Profil Desa Senganan".

Dananjaya, I.G.A.N. 2020. Pengaruh Integrasi Ternak Kambing Dan Tanaman Kopi Terhadap Pendapatan Kelompok Tani Ternak Satwa Amerta, Di Desa Mundeh, Kecamatan Selemadeg Barat, Kabupaten Tabanan. Jurnal dwijenAGRO, Vol. 10. No.1.

Murtijo, B.A. 1987. Pedoman Beternak Ayam Broiler. Jakarta : Kanisius.

Pandang, A.M.H. 2004. Dampak Usaha Peternakan Ayam Ras Petelur terhadap Lingkungan Masyarakat Bukan Peternak. Fakultas Peternakan, Universitas Udayana.

Pranowo, D. 1985. Masyarakat Desa (Tinjauan Sosiologi). Surabaya : Bina Ilmu.

Sedana, G. I G.A.A.Ambarawati, and W. Windia. (2014). Strengthening Social Capital for Agricultural Development: Lessons from Guama, Bali, Indonesia. Asian Journal of Agriculture and Development. Vol.11 No.2:39-50.

Sedana, G. and N.D. Astawa. (2016). Panca Datu Partnership in Support of Inclusive Business for Coffee Development:The Case of Ngada District, Province of Nusa Tenggara Timur, Indonesia. Asian Journal of Agriculture and Development, Vol. 13, No.2: 75-98.

Sedana, G. (2020). Benefits of farmers' cooperative to rice farming activity: case of Subak's cooperative in Guama, Tabanan District, Bali province. IOP Conference Series: Earth and Environmental Science, Volume 484 (2020):012134.

Sedana, G. and A. Rahmat. (2020). Alternative Policies to Strengthen the Traditional Irrigation System for Supporting the Food Security Program: Case of The Subaks' System in Bali, Indonesia. International Journal of Advanced Science And Technology, Vol. 29, No. 7s: 973-984

Soeparno, H.A. 1988. Wawasan Lingkungan Hidup. Surabaya: Airlangga University Press.

Sugiyono, 2006. Metode Penelitian Bisnis. Bandung: CV. Alfabeta.

Suparta, N. 2005. Pendekatan Holistik Mambangun Agribisnis.Cetakan I, Juni 2005. Denpasar: CV Bali Media Adhikarsa.

Suparta, N. dan I Wayan Ramantha. 2010. Manajemen Bisnis Kecil \& Kewirausahaan. Cetakan Pertama, Juni 2010. Denpasar: Pustaka Nayottama. 